\title{
Validation of the Big Five Questionnaire (BFQ-C), short version, in Colombian adolescents
}

\author{
Claudia A. Robles-Haydar, ${ }^{1}$ José Amar-Amar, ${ }^{2}$ Marina B. Martínez-González
}

Departamento de Ciencias Sociales, Universidad de la Costa, Barranquilla, Colombia.

2 Centro de Investigación en Desarrollo Humano, Universidad del Norte, Barranquilla, Colombia.

\section{Correspondence:}

Marina B. Martínez-González

Departamento de Ciencias Sociales,

Universidad de la Costa.

Cl. 58 \#55-66, Barranquilla,

Atlántico, Colombia

Email: mmartine21@cuc.edu.co

Received: 5 March 2021

Accepted: 11 November 2021

Citation:

Robles-Haydar, C. A. Amar-Amar, t.

\& Martínez-González, M. B. (2022)

Validation of the Big Five Questionnaire (BFQ-C), short version, in Colombian adolescents. Salud Mental, 45(1), 29-34.

DOI: $10.17711 /$ SM. 0185-3325.2022.005

\begin{abstract}
Introduction. The most widely accepted theoretical and measurement model in personality study is the Big Five Personality Test, designed to measure five traits: Extraversion, Agreeableness, Conscientiousness, Neuroticism, and Openness. One of the most commonly used instruments for evaluating personality in children and adolescents is the BFQ-C. However, its applicability may be limited by its length. The short version of the test has shown stability across different cultures but there is no empirical evidence on its psychometric properties to enable it to be used in the Latin American context. Objective. This study seeks to validate the short version of the Big Five Questionnaire for Children (BFQ-C) in the Colombian population. Method. The questionnaire was administered to 844 adolescents ( $55 \%$ boys and $45 \%$ girls) aged between 11 and $16(M=13.55$ and $S D=2.30)$. Seven possible models were obtained from a series of exploratory and confirmatory analyses to explain the factorial structure of the test, which were compared with each other to find the model with the best statistical fit. Results. The model with the best absolute fit coincided with the five-factor proposal of the scale, for which empirical evidence is provided for the universality of the Big Five model. The factors showed adequate levels of reliability. Discussion and conclusion. The short version of the BFQ-C has good psychometric properties in adolescents and constitutes a useful instrument for measuring personality in the Latin American context.
\end{abstract}

Keywords: Personality, Big Five Model, adolescents, psychometrics.

\section{RESUMEN}

Introducción. El modelo teórico y de medición más aceptado en el estudio de la personalidad es el de los Cinco Grandes: Energía, Amabilidad, Conciencia, Inestabilidad Emocional y Apertura a la Experiencia. El BFQ-C es uno de los instrumentos más usados para evaluar a niños y adolescentes. No obstante, su aplicabilidad puede verse limitada por su extensión. Aunque la versión corta ha evidenciado cierta estabilidad en distintas culturas, no hay evidencia empírica sobre sus propiedades psicométricas para usarse en el contexto latinoamericano. Objetivo. Validar en población colombiana la versión corta del Cuestionario de los Cinco Grandes para Niños (BFQ-C). Método. Se aplicó el cuestionario a 844 adolescentes (55\% hombres y $45 \%$ mujeres), con edades entre los 11 y los 16 años $(M=13.55$ y $S D=2.30)$. A partir de una serie de análisis exploratorios y confirmatorios, se obtuvieron siete modelos posibles para explicar la estructura factorial de la prueba; éstos se compararon entre sí para hallar el modelo con el mejor ajuste estadístico. Resultados. El modelo con el mejor ajuste absoluto coincidió con la propuesta pentafactorial de la escala, por lo que se ofrece evidencia empírica para la universalidad del modelo de los Cinco Grandes. Los factores evidenciaron niveles de confiabilidad adecuados. Discusión y conclusión. En su versión corta, el BFQ-C presenta buenas propiedades psicométricas en adolescentes y constituye un instrumento útil para la medición de la personalidad en el contexto latinoamericano.

Palabras clave: Personalidad, Modelo de los Cinco Grandes, adolescentes, propiedades psicométricas. 


\section{INTRODUCTION}

The study of personality is of great interest in psychology because it is a construct that contributes to the explanation of both socially valued behaviors and maladaptive and psychopathological ones (Abihssira García, 2019; Alarcón, Pérez-Luco, Wenger, Salvo, \& Chesta, 2018; Caprara et al., 2017; González-Hernández \& Ato-Gil, 2019). Although the concept is derived from different approaches, it can be understood as a series of individual attributes that are stable over time, gives subjects a sense of identity, integrity, and uniqueness, and provides them with a certain regularity in their behaviors (Caprara \& Cervone, 2000). Current psychological research has focused on the Big Five Personality Traits model comprising the following variables: Extraversion, Agreeableness, Conscientiousness, Neuroticism, and Openness to Experience (Cupani, Sánchez, Gross, Chiepa, \& Dean, 2013; Edo et al., 2002; Olivier \& Herve, 2015). Its popularity lies in the fact that it offers the possibility of creating a common framework for the evaluation of personality through a five-factor structure, validated in different cultures and age groups (Edo et al., 2002).

The extraversion factor reflects the ability to make friends and experience positive emotions; agreeableness is associated with empathy and warmth in interpersonal relationships (Caprara, Barbaranelli, Borgogni, \& Perugini, 1993), and conscientiousness is related to impulse control and determination in goal achievement (Caprara et al., 1993). Neuroticism refers to the tendency to experience negative emotions (Cassaretto, 2009), while openness comprises aspects such as intellectual curiosity, appreciation for art, and tolerance for divergent ideas (Simkin, Etchezahar, \& Ungaretti, 2012).

Several instruments have been designed to measure the Big Five in adults (Caprara et al., 1993; Costa \& McCrae, 2008; Goldberg, 1992), while versions for children and adolescents include the 240-item NEO-PI-RJ (Edo et al., 2002) and the 65-item BFQ-C (Barbaranelli, Caprara, Rabasca, \& Pastorelli, 2003).

The latter has been validated in the Netherlands $(\mathrm{Mu}-$ ris, Meesters, \& Diederen, 2005), Spain (Carrasco-Ortiz, Holgado-Tello, \& del Barrio-Gandara, 2005; del Barrio, Carrasco, \& Holgado, 2006; Soto et al., 2011), France (Olivier \& Herve, 2015), and Argentina (Cupani, Morán, Ghío, Azpilicueta, \& Garrido, 2020; Cupani \& Ruarte, 2008), confirming the reliability and the five-factor structure of the scale. A study conducted in Spain showed a better fit with a four-factor model (Holgado-Tello, Carrasco-Ortiz, del Barrio-Gándara, \& Chacón-Moscoso, 2009), although this difference may be explained by the fact that it used polychoric rather than Pearson matrices, which were used in previous studies (Holgado-Tello et al., 2009).

Since the existing instruments have too many questions for the under-12 population (Beatton \& Frijters, 2012), short versions of the BFQ-C that keep the five-factor structure of the construct and maintain adequate reliability indicators have also been developed. Short versions of the BFQ-C have been validated in Italy (Mamazza, 2012), Russia (Kuzmina et al., 2018), Australia (Bore et al., 2020), Greece (Markos \& Kokkinos, 2017) and Korea (Kim \& Kim, 2012).

\section{Objective}

Due to the lack of validation of the short version of the BFQ-C in the Latin American context, this research focused on analyzing its psychometric properties in a sample of Colombian adolescents.

\section{METHOD}

\section{Study design}

A psychometric study was conducted with a cross-cutting design.

\section{Subjects}

Participants were 844 adolescents between 11 and 16 years of age ( $M=13.55$ and $S D=2.30), 464$ of whom $(55 \%)$ were boys. All of them were contacted at educational institutions in the city of Barranquilla, Colombia.

\section{Measurements}

The study used the short version of the BFQ-C translated into Spanish. Positively scored items reflect six behaviors per trait. Answer choices range from 1 (almost never) to 5 (almost always). The original version of the instrument validated with Italian adolescents has satisfactory reliability and validity results, with a Cronbach's alpha ranging from .65 to .85 for each of the scales (Mamazza, 2012).

\section{Procedure}

The educational institutions received written information on the project, as well as the test protocols and their ethical aspects. Tests were administered on a single day during the regular class schedule with the support of two researchers and the students' respective teachers in the institutions that agreed to participate. Only students who agreed to participate and had the consent of their parents were included in the sample.

\section{Statistical analysis}

The factorial structure was analyzed using the two-step method (Anderson \& Gerbing, 1988) involving exploratory factor analysis [EFA] and confirmatory factor analysis [CFA]. 
For the EFA, the criteria included an eigenvalue higher than or equal to $1[\lambda>1]$; explained variance higher than or equal to $60 \%\left[60 \% \delta^{2} \exp \right]$; the Kaiser criterion; and the theoretical five-factor model of the scale. Criteria based on resampling or bootstrapping were also considered to minimize the effect of bias due to random capitalization. These criteria included the Minimum Average Partial Test (MAP) and Parallel Analysis (PA), both optimal and classical. In all cases, the extraction method chosen was the Principal Components method and Varimax rotation, due to the assumption of factorial independence.

Polychoric (PolychoricCM) and Pearson (PearsonCM) matrices were used for CFA.

In the analysis, Unweighted Least-Squares (ULS) were used for the models obtained by PolychoricCM, whereas Maximum Likelihood (ML) was used for the models obtained by PearsonCM. Both methods were used to analyze the theoretical model of the scale and the one obtained through bootstrapping.

Absolute, incremental, and parsimony fit indicators were extracted. Among the absolute adjustment indicators, the following were evaluated: X2 Ratio $(X 2 / g l)$; X2 Significance ( $P$-value of $X 2)$; RMSEA goodness-of-fit index (GFI); Root mean square error of approximation (RMSEA); RMSEA Significance ( $P$-value RMSEA); and the Non-Centrality Parameter $(N C P)$.

The following incremental adjustment indicators were obtained: Adjusted goodness-of-fit index ( $A G F I)$; NonNormed Fit Index (NNFI); Normed Fit Index (NFI) and Comparative Fit Index (CFI).

The following were evaluated for the parsimony indicators: the Parsimony Normed Fit Index (PNFI) and the Parsimony Goodness of Fit Index (PGFI).

Reliability analysis was based on McDonald's omega and Cronbach's alpha using JASP. Average inter-item correlation was also analyzed.

\section{Ethical considerations}

The entire procedure was conducted in accordance with the Declaration of Helsinki (revised in Brazil, 2013) and approved by the Ethics Committee of the Universidad del

Table 1

Fit measures for Factors Evaluated

\begin{tabular}{|c|c|c|c|c|c|c|c|c|c|}
\hline \multirow[b]{3}{*}{ Fit indicators } & \multicolumn{9}{|c|}{ Model No. } \\
\hline & \multirow{2}{*}{$\frac{1}{M L}$} & \multirow{2}{*}{$\begin{array}{c}2 \\
M L\end{array}$} & \multicolumn{2}{|c|}{3} & \multirow{2}{*}{$\frac{4}{U L S}$} & \multirow{2}{*}{$\frac{5}{U L S}$} & \multirow{2}{*}{$\frac{6}{U L S}$} & \multicolumn{2}{|c|}{7} \\
\hline & & & $M L$ & ULS & & & & $M L$ & ULS \\
\hline \multicolumn{10}{|l|}{ Absolute fit measures } \\
\hline$\left[x^{2}\right]$ & 1150.2 & 998.6 & 1305.6 & 1313.1 & 1192.1 & 4076.6 & 2688.3 & 1305.6 & 1334.5 \\
\hline Ratio $x^{2}$ & 3.0 & 2.71 & 3.31 & 3.32 & 3.06 & 10.09 & 6.69 & 3.31 & 3.38 \\
\hline P-value of $X^{2}$ & .0 & .0 & .0 & .0 & .0 & .0 & .0 & .0 & .0 \\
\hline GFI & .92 & .93 & .91 & .95 & .95 & .87 & .92 & .91 & .95 \\
\hline RMSEA & .05 & .045 & .052 & .053 & .049 & .100 & .082 & .052 & .053 \\
\hline P-value of RMSEA & .75 & .990 & .110 & .093 & 620 & .000 & .000 & .110 & .050 \\
\hline NCP & 766.22 & 629.66 & 910.57 & 918.05 & 802.1 & 3672.6 & 2286.3 & 910.57 & 939.47 \\
\hline ECVI & 1.56 & 1.41 & 1.71 & 1.72 & 1.59 & 4.98 & 3.34 & 1.71 & 1.75 \\
\hline RMSR & .055 & .051 & .057 & .056 & .053 & .090 & .071 & .057 & .055 \\
\hline \multicolumn{10}{|l|}{ Incremental fit measures } \\
\hline AGFI & .90 & .91 & .89 & .94 & .95 & .85 & .91 & .89 & .94 \\
\hline NNFI & .94 & .95 & .93 & 1.03 & 1.03 & 1.03 & 1.03 & .93 & 1.03 \\
\hline $\mathrm{NFI}$ & .92 & .93 & .91 & 1 & 1 & 1 & 1 & .91 & 1 \\
\hline $\mathrm{CFI}$ & .95 & .95 & .94 & 1 & 1 & 1 & 1 & .94 & 1 \\
\hline \multicolumn{10}{|l|}{ Parsimony fit measures } \\
\hline PNFI & .81 & .79 & .83 & $.91^{*}$ & .90 & $.93^{* *}$ & $.92^{*}$ & .83 & $.91^{*}$ \\
\hline PGFI & .76 & .74 & .77 & $.81^{* *}$ & $.80^{*}$ & .76 & $.80^{\star}$ & .77 & $.81^{* *}$ \\
\hline $\begin{array}{l}\text { No. of fit measures that meet } \\
\text { criteria }\end{array}$ & 6 & 9 & 6 & 9 & 7 & 7 & 9 & 6 & 10 \\
\hline
\end{tabular}

Notes: Values with * indicate that there is no substantial difference from the máximum and values with ** indicate that it is the maximum value.

$\mathrm{GFI}=$ Goodness of fit index; RMSEA = Root Mean Square Error of Approximation; NCP = Non-Centrality Parameter; ECVI = Expected Cross Validation Index; RMSR = report root-mean-square residuals; AGFI = Adjusted Goodness of Fit Index; NNFI = Non-Normed Fit Index; NFI = Normed Fit Index; CFI = Comparative Fit Index; PNFI = Parsimony Normed Fit Index; PGFI = Parsimony Goodness of Fit Index. 
Table 2

Statistics for the Reliability Index of Internal Consistency

\begin{tabular}{|c|c|c|c|c|c|}
\hline & Mean & $S D$ & Cronbach's $\alpha$ & McDonald's $\omega$ & $\begin{array}{c}\text { Average inter-item } \\
\text { correlation }\end{array}$ \\
\hline Factor 1 (Neuroticism) & 3.486 & .241 & .846 & .853 & .486 \\
\hline Factor 2 (Extraversion) & 3.412 & .427 & .743 & .746 & .327 \\
\hline Factor 3 (Agreeableness) & 3.701 & .276 & .712 & .734 & .307 \\
\hline Factor 4 (Conscientiousness) & 2.513 & .156 & .728 & .738 & .314 \\
\hline Factor 5 (Openness) & 3.331 & .395 & .640 & .646 & .231 \\
\hline
\end{tabular}

Note: Observations are based on the answers of 844 subjects without missing data.

Norte, file number 146. Questionnaires were completed anonymously.

\section{RESULTS}

\section{Exploratory and confirmatory factor analysis}

First step EFA. The assumption of multivariate normality was confirmed and the existence of an underlying factorial structure in the BFQ-C answers was proven, since the value of the determinant (D) of both inter-item correlation matrices was close to the zero criterion $\left(D_{\text {Pearson }}=.0003 ; D_{\text {Polycho- }}\right.$ $\left.r_{\text {ric }}=.0002\right)$, like the significance measure of Bartlett's test of sphericity $\left(P\right.$-value $_{\text {Pearson }}=.000 ; P$-value Polychoric $\left._{1}=.000\right)$. The results of the sampling adequacy of Kaiser, Meyer, and Olkin $[\mathrm{KMO}]$ were above the criterion of .5 , with a value of .87 for both matrices $\left(K M O_{\text {Pearson }}=.87 ; K M O_{\text {Polychoric }}=.87\right)$.

Initially, 18 possible models were identified for the factorial structure of the scale, organized as follows: nine models for the ${ }_{\text {Pearson }} C M$ and nine for the Polychoric $C M$. Four models were rejected because they contained factorial solutions including factors without an item load (Freiberg-Hoffmann, Stover, de la Iglesia, \& Fernández-Liporace, 2013). Likewise, several models were repeated in different criteria, as a result of which, at the end there were a total of seven possible solutions for the explanation of the factorial structure of the test, of which Model No. 7 displayed five factors, which tallied with the theoretical model of the scale.

Second step CFA. The models obtained were compared with each other through the rival model strategy, whereby their indicators of absolute, incremental, and parsimony fit were evaluated, until the best fit was identified (Table 1).

Beginning with the absolute adjustment measures, the following models stood out: No. 2 and No. 7urs. In the incremental adjustment indicators, the following models were noticeable: No. 4, No. $3_{\text {Uls, }}$ and No. 7 urs. For the parsimony adjustment measures, models No. 5, as well as No. 3 ULs and No. 7 ULS attracted attention. Models No. $3_{\text {ULS }}$ and No. 7 ULS showed the best adjustments in several indicators. Both models corresponded to a five-factor solution with the only difference being found in the location of item 24: "I think other people are good and honest." In model No. $3 \mathrm{ULS}$ this item belongs to the Extraversion factor, since it probably shows an aspect of sociability, whereas in model No. $7_{\text {ULS }}$ it forms part of the Agreeableness factor, due to its relationship with empathy and concern for others.

In model No. $7_{\text {ULS }}$, it showed the best RMSEA significance, which is why it is considered the best statistical fit of all, since it complies with 10 indicators. This model was derived from the theoretical criterion of the scale based on the polychoric matrices.

\section{Internal consistency analysis}

The results for McDonald's omega and Cronbach's alpha of the factors were above .7, which is considered good, except for factor 5 (openness), where the values were .65 and .64, respectively, indicating acceptable reliability (Alomi \& Rayah, 2020). As for the average inter-item correlation, it was found that the factors showed values between .3 and .4 , which can be considered ideal, except for factor 5 , for which the score was .23 , which is regarded as acceptable (Hajjar, 2018) (Table 2).

\section{DISCUSSION AND CONCLUSION}

This research validated the short version of the BFQ-C that measures personality in children and adolescents and found a high reliability of the instrument and consistency of the structural analysis with the theoretical model of the Big Five. The results showed that the short version of the BFQ-C translated into Spanish has psychometric properties equivalent to the full version and evidenced a strong convergence with theoretically relevant external criteria that support the universality of the Big Five model.

Although a previous study found a factorial solution of four factors, it used only polychoric matrices for its analysis (Holgado-Tello et al., 2009). The present study incorporated both polychoric and Pearson matrices and maintained the original five-factor structure. Since polychoric matrices 
showed a better fit in their models, it would be more appropriate to use these rather than Pearson's in studies that incorporate factor analysis techniques (Domínguez-Lara, 2014; Lorenzo-Seva \& Ferrando, 2020).

The Big Five model has shown that its factors are independent of culture and remain stable across the life cycle (Bore et al., 2020; Kim \& Kim, 2012; Kuzmina et al., 2018; Lemos, 2006; Markos \& Kokkinos, 2017). As a common framework in the study of personality, it would encourage the incorporation of psychodiagnostics, the establishment of comparisons between different research projects, and the study of the evolution of the human personality from childhood up to adulthood, which would allow a better understanding of evolutionary development and ultimately human nature (Lemos, 2006).

This research validated the psychometric characteristics of the short version of the BFQ-C translated into Spanish, finding high reliability and validity of the factorial structure in keeping with the theoretical model of the Big Five underpinning the test, which is a step in the right direction for its use with the Latin American child and adolescent population.

\section{Funding}

This research was funded by the doctoral scholarship program of the Ministry of Science, Technology, and Innovation of Colombia.

\section{Conflict of interest}

The authors declare that they have no conflicts of interest.

\section{REFERENCES}

Abihssira García, L. L. (2019). Rasgos de la Personalidad y Creatividad Determinantes en la Calidad y la Creatividad en Traducción. Colección Artes y Humanidades. Universidad de Murcia, Esp. https://digitum.um.es/digitum/ handle/10201/71141

Alarcón, P. A., Pérez-Luco, R. X., Wenger, L. S., Salvo, S. I., \& Chesta, S. A. (2018). Personalidad y gravedad delictiva en adolescentes con conducta antisocial persistente. Revista Iberoamericana de Psicología y Salud, 9(1), 58-74. doi: 10.23923/j.rips.2018.01.015

Alomi, Y. A., \& Rayah, I. H. A. A. (2020). Reliability and Validity of Biostatical Analysis used for Pharmacy Research Questionnaire in Saudi Arabia. Pharmacology, Toxicology and Biomedical Reports, 6(3), 96-104. doi: 10.5530/ PTB.2020.6.18

Anderson, J. C., \& Gerbing, D. W. (1988). Structural equation modeling in practice: A review and recommended two-step approach. Psychological Bulletin, 103(3), 411-423. doi: 10.1037/0033-2909.103.3.411

Barbaranelli, C., Caprara, G. V., Rabasca, A., \& Pastorelli, C. (2003). A questionnaire for measuring the Big Five in late childhood. Personality and Individual Differences, 34(4), 645-664. doi: 10.1016/S0191-8869(02)00051-X

Beatton, T., \& Frijters, P. (2012). Unhappy Young Australian: A domain approach to explain life satisfaction change in children. Working/Discussion Paper \# 289, pp. 1-42. QUT School of Economics and Finance. https://melbourneinstitute. unimelb.edu.au/assets/documents/hilda-bibliography/working-discussionresearch-papers/2012/Beatton_etal_Unhappy_Young_Australian.pdf

Bore, M., Laurens, K. R., Hobbs, M. J., Green, M. J., Tzoumakis, S., Harris, F., \& Carr, V. J. (2020). Item Response Theory Analysis of the Big Five Questionnaire for Children-Short Form (BFC-SF): A Self-Report Measure of Personality in Children Aged 11-12 Years. Journal of Personality Disorders, 34(1), 40-63. doi: 10.1521/pedi_2018_32_380
Caprara, G. V., \& Cervone, D. (2000). Personality: Determinants, Dynamics, and Potentials (1st Ed.). Cambridge University Press. doi: 10.1017/ CBO9780511812767

Caprara, G. V., Barbaranelli, C., Borgogni, L., \& Perugini, M. (1993). The "big five questionnaire": A new questionnaire to assess the five factor model. Personality and Individual Differences, 15(3), 281-288. doi: 10.1016/0191-8869(93)90218-r

Caprara, G. V., Gerbino, M., Perinelli, E., Alessandri, G., Lenti, C., Walder, M., ... Nobile, M. (2017). Individual Differences in Personality Associated with Aggressive Behavior among Adolescents Referred for Externalizing Behavior Problems. Journal of Psychopathology and Behavioral Assessment, 39(4), 680692. doi: 10.1007/s10862-017-9608-8

Carrasco-Ortiz, M. Á., Holgado-Tello, F. P., \& del Barrio-Gandara, M. V. (2005). Dimensionalidad del cuestionario de los cinco grandes (BFQ-N) en población infantil española. [Big five questionnaire dimensions in Spanish children (BFQ-C).]. Psicothema, 17(2), 286-291.

Cassaretto, M. (2009). Relación entre las cinco grandes dimensiones de la personalidad y el afrontamiento en estudiantes pre-universitarios de Lima Metropolitana. Universidad Nacional Mayor De San Marcos, Lima.

Costa, P. T., \& McCrae, R. R. (2008). The Revised NEO Personality Inventory (NEOPI-R). In The SAGE Handbook of Personality Theory and Assessment: Volume 2-Personality Measurement and Testing (pp. 179-198). SAGE Publications Ltd. doi: 10.4135/9781849200479.n9

Cupani, M., \& Ruarte, M. (2008). Propiedades psicométricas del Cuestionario de los Cinco Factores para Niños (BFQ-C) en una muestra de adolescentes argentinos. Estudios de Psicología, 29(3), 351-364. doi: 10.1174/021093908786145421

Cupani, M., Morán, V. E., Ghío, F. B., Azpilicueta, A. E., \& Garrido, S. J. (2020). Psychometric Evaluation of the Big Five Questionnaire for Children (BFQ-C): A Rasch Model Approach. Journal of Child and Family Studies, 29(9), 24722486. doi: 10.1007/s10826-020-01752-y

Cupani, M., Sánchez, D., Gross, M., Chiepa, J., \& Dean, R. (2013). El modelo de los cinco factores y su relación con los trastornos de personalidad. Revista de Peruana de Psicología y Trabajo Social, 2(2), 31-46.

del Barrio, V., Carrasco, M. A., \& Holgado, F. P. (2006). Factor Structure Invariance in the Children's Big Five Questionnaire. European Journal of Psychological Assessment, 22(3), 158-167. doi: 10.1027/1015-5759.22.3.158

Domínguez-Lara, A. (2014). ¿Matrices policóricas/tetracóricas o matrices Pearson? Un estudio metodológico. Revista Argentina de Ciencias Del Comportamiento (RACC), 6(1), 39-48. doi: 10.32348/1852.4206.v6.n1.6357

Edo, S., Moya, J., Lores, J., Luelmo, V., Ibañez, M., \& Ortet, G. (2002). Estudio psicométrico de la versión española del Cuestionario de los Cinco Grandes para Niños (BFQ-N). Fòrum de Recerca, 8, 1-8. Retrieved from http://hdl.handle. net/10234/79660

Freiberg-Hoffmann, A., Stover, B., de la Iglesia, G., \& Fernández-Liporace, M. (2013). Correlaciones policóricas y tetracóricas en estudios factoriales exploratorios y confirmatorios. Ciencias Psicológicas, 7(2), 151-164.

Goldberg, L. R. (1992). The development of markers for the Big-Five factor structure. Psychological Assessment, 4(1), 26-42. doi: 10.1037/1040-3590.4.1.26

González-Hernández, J., \& Ato-Gil, N. (2019). Relación de los rasgos de personalidad y la actividad física con la depresión en adolescentes. Revista de Psicología Clínica con Niños y Adolescentes, 6(1), 29-35. doi: 10.21134/rpcna.2019.06.1.4

Hajjar, S. E. (2018). Statistical analysis: internal-consistency reliability and construct validity. International Journal of Quantitative and Qualitative Research Methods, 6(1), 46-57.

Holgado-Tello, F. P., Carrasco-Ortiz, M. Á., del Barrio-Gándara, M. V., \& ChacónMoscoso, S. (2009). Factor analysis of the Big Five Questionnaire using polychoric correlations in children. Quality \& Quantity, 43(1), 75-85. doi: 10.1007/s11135-007-9085-3

Kim, B.-H., \& Kim, J.-H. (2012). Validation of Korean short version of the big five questionnaire for children. The Korean Journal of Elementary Counseling, 11(3), 371-390.

Kuzmina, Y., Rean, A., Zinchenko, Y., Fenin, A., Malykh, A., Kovas, Y., \& Malykh, S. (2018). Bfq-Rb(Russian Brief): Short Big-Five Questionnaire to Measure Facets and Factors of Personality (pp. 326-337). doi: 10.15405/epsbs.2018.11.02.37

Lemos, V. (2006). La evaluación de la personalidad infantil a partir del enfoque de los cinco grandes factores de personalidad (Big Five). Psicodiagnosticar, 16, 97-108. 
Lorenzo-Seva, U., \& Ferrando, P. J. (2020). Not Positive Definite Correlation Matrices in Exploratory Item Factor Analysis: Causes, Consequences, and a Proposed Solution. Structural Equation Modeling: A Multidisciplinary Journal, 28(1), 138-147. doi: 10.1080/10705511.2020.1735393

Mamazza, L. (2012). Lo studio della personalità in una prospettiva longitudinale: Misura e relazioni con intelligenza, profitto scolastico e indicatori di buono / cattivo adattamento (Tesis Doctoral). Università degli Studi di Padova. Retrieved from http://paduaresearch.cab.unipd.it/4489/

Markos, A., \& Kokkinos, C. M. (2017). Development of a short form of the Greek Big Five Questionnaire for Children (GBFQ-C-SF): Validation among preadolescents. Personality and Individual Differences, 112, 12-17. doi: 10.1016/j.paid.2017.02.045

Muris, P., Meesters, C., \& Diederen, R. (2005). Psychometric properties of the Big Five Questionnaire for Children (BFQ-C) in a Dutch sample of young adolescents. Personality and Individual Differences, 38(8), 1757-1769. doi: 10.1016/j.paid.2004.11.018
Olivier, M., \& Herve, M. (2015). The Big Five Questionnaire for Children (BFQ-C): A French validation on 8- to 14-year-old children. Personality and Individual Differences, 87, 55-58. doi: 10.1016/j.paid.2015.07.030

Simkin, H., Etchezahar, E., \& Ungaretti, J. (2012). Personalidad y Autoestima desde el modelo y la teoría de los Cinco Factores. Hologramática, 7(17), 171-193. Retrieved from http://psicologiasocial.sociales.uba.ar/wp-content/ uploads/sites/162/2013/06/Simkin_Etchezahar_Ungaretti_-_2012_Personalidad_y_Autoestima_desde_el_modelo_y_la_teoria_de_los_Cinco_ Factores 1-libre.pdf

Soto, G., Ferrándiz, C., Sáinz, M., Ferrando, M., Prieto, M. D., Bermejo, R., \& Hernández, D. (2011). Características psicométricas del cuestionario de personalidad BFQ-NA (Big Five Questionnaire-Niños y Adolescentes). Aula Abierta, 39(1), 13-24. 